\title{
Founding acts: Constitutional Origins in a Democratic Age
}

Serdar Tekin

University of Pennsylvania Press, Philadelphia, 2016, 196pp., ISBN: 978-0812248289

Ever since Rousseau, democratic political theory has tried to come to terms with the fact that institution of a democracy depends on its undemocratic first positing, i.e. on a declaration, or a founding act, or a highest law that is not authorized by the people. In his book, Serdar Tekin offers an interpretation of the founding paradox from the perspective of deliberative democratic theory. The reasons for this fresh look are drawn from the Arab Spring events from 2010 to 2012, and especially, from Egypt's failure after the revolution to establish itself as a democratic regime. Tekin argues that our current democratic political practice, informed by the idea of popular sovereignty, presumes the people as a uniform entity, but the people today is a plurality. Because of this incongruity, new democratic founding acts succumb, on the one side, into mishandling of power and suppression of differences, as happened in Egypt after the revolution, or on the other side, into the deficit of legitimacy, since the founding act does not receive the authorization of the entire people. In order to remedy this situation, Tekin proposes a kind of deliberative model of founding with a strong emphasis on actual democratic participation of people in the founding act, because, as he says, it matters how constitutions are started (p. 2).

Tekin needs to address two aspects to prove his case: the necessity for and the possibility of his solution. In regard to necessity, he first responds to Kant's so-called "hypothetical account of popular sovereignty”, where the founding act is posited as an idea of reason, without any actual consent of the people. Secondly, he considers a few empirical cases where democratic regimes have been founded on undemocratically devised constitutions, like in Germany, in Japan, and in Quebec of Canada. As concerns the cases, he points out their exceptionality, which might 
or might not convince a reader. But his engagement with Kant is rather thin. In the final analysis, his argument against Kant rests on an intuition that in today’s world, Kant's abstract reasoning does not convince anybody, especially those who are actually in the process of founding something. Later, he somewhat qualifies his argument to be moral rather than epistemic, saying that it is epistemic only in its weaker version, that is, actual deliberation would increase the likelihood of validity, but morally, it would be commendable that the founding act should performatively manifest the values it wants to propagate (p. 150).

Much more space is devoted to the other aspect of possibility of his deliberative agencyoriented solution, for democratically founding a democratic constitution is a paradoxical endeavor. Tekin restates the paradox in two forms. The first version concerns a democratic ethos: in order to first organize themselves democratically, people must have been living democratically for some time to want to proceed in this way. The second version targets the formal authorization or legitimacy: there is no people as an entity to authorize the founding act, for the founding act creates the people in the first place.

Tekin's aim is to defend the possibility of his deliberative founding act by demonstrating a negotiability of the paradox. He condemns all hypostatization of the paradox, by which he means transposing "the formal or logical structure of the paradox onto the realm of political action” (p. 10). With this, he has in mind, especially, all theorists of post-structuralist bent, who have stressed the irreducibility of the paradox, like Jacques Derrida, Bonnie Honig, and William Connolly. Instead of hypostatization, he proposes to interpret the paradox as a heuristic problem, which, rather than being simply aporetic, inspires finding ways to negotiate it.

In regard to the first version of the paradox, his main strategy to bolster his heuristic approach is to relativize the founding act itself, which, as he says, “opens up to us a grey area, in which the conditions of democratic peoplehood are in the making” (p. 10). He takes two iconic 
theoreticians of democratic founding, Rousseau and Arendt, and by interpreting their texts, he shows, firstly, that the people always already exist as if prior to the founding act (Rousseau), and secondly, after the founding act has taken place, they still do not quite yet exist as a people, as an entity (Arendt). He argues that that the Great Lawgiver in Rousseau is not only an architect who gives laws to the people, but he also is an interpreter, for "it is the collective action of the people and the kind of receptivity generated in the course of such action that calls forth the lawgiver” (p. 68). In that case, as Tekin argues against Honig's and Connolly’s interpretations, the Great Lawgiver does not mark the aporetic paradox, but (also) a possibility of negotiation. In respect to Arendt, Tekin points out that in The Jewish Writings, Arendt talks not about founding a state with a specific ethnic identity, but about a homeland, which, being:

... a particular kind of 'we' is neither simply their inherited identity nor an abstract idea such as consent. Rather it is the artificial space which opens up in-between them as a result of their own agency, a space which provides them with a 'world', a context of meaning, belonging, and solidarity. (p. 87)

Tekin sees in Arendt an indication how to think identity that is coeval with acting, i.e. the founding act does not conclusively establish an identity, but it remains to be (re)constructed over again by the people acting together.

So, on the basis of his readings of Rousseau and Arendt, Tekin suggests that the founding decision can be replaced by a deliberation, for the founding is a process, always "in the making."

In his take on the second version of the paradox, which is negotiated via Arendt's concept of the principle in On Revolutions, Tekin somewhat balances out the process by highlighting the moment of founding. Tekin argues that, for Arendt, every founding act contains in itself a principle, which refers to a certain spirit that describes how the founding act came to be, and which remains to inspire the people after the act (p. 117). Even if Tekin's interpretation of the 
principle as a spirit is entirely viable, it still raises many questions: in what sense Arendt’s “mutual promise and common deliberation” make up a spirit of a founding act, and how the spirit is commonly recognized, or who and when decides about what the spirit is and what actions correspond to it. On the basis of his analysis, Tekin proposes a founding process based on direct participation and deliberation, which moves back and forth between designers of the constitution and the people.

If read by focusing on the arguments in its individual chapters, this is a well written book. Individual chapters make valuable points of analysis (chapters on Rousseau and Arendt being stronger ones) and uphold their own argument. In its style, it is written in easily accessible language and well structured, covering all the most relevant authors for his argument. However, the argument of the book as a whole remains thin. Basically, Tekin seeks to theorize the following intuition: when a group of human beings has come together to agree on something that affects all of them, they have many diverse opinions and interests, which can only be overcome by negotiations and deliberations, if this collective is to be preserved (or established) as a group of equals. The appeal of this intuition for Tekin comes from its seemingly practical utility in making democratic founding acts successful. This is something that paradoxes seemingly do not offer, but this is exactly where Tekin's theoretical analysis gets skewed.

To start with, Tekin equates the founding act with constitution-making, and also in his mention of Derrida, he glosses over the fact that Derrida does not speak about constitutions but declarations. But no state is founded by a constitution. We could recall here Carl Schmitt: "There exists no norm that is applicable to chaos. For a legal order to make sense, a normal situation must exist” (Schmitt 2005: 13). In this context, we should distinguish a regime change from a founding act, for if the latter is declared up against an other(s) who is left outside, a regime change has its others inside it. Also, if a less essentialist concept of the people were used, the 
paradox in the declarative act could have been maintained without it becoming a threat to initiation of the constitution-making, which indeed is always a process, adapting to changing attitudes of the people. In this respect, it would have been useful to study Ernesto Laclau's book On the Populist Reason, in which the people is neither simply a unity nor disunity, or an inbetween of an "amorphous multitude” and a “corporate body,” but is being constructed into one or another under specific political circumstances.

Although, Tekin partially recognizes that the founding paradox guarantees our democratic freedom and opens every constitution to its amendments, he is not able to accommodate it into his practical task to help democratic revolutions succeed. Therefore, he tries to bridge the paradox. Even if he does not succeed, Tekin still might have pacified the minds of theory conscious revolutionaries of our time to proceed with their democratic founding acts.

\section{Andro Kitus}

Marie Skłodowska-Curie Research Fellow

University at Buffalo, Buffalo, NY 14260, USA

Queen Mary, University of London, London, E1 4NS, UK

androkit@buffalo.edu

\section{References}

Laclau, E. 2005. On Populist Reason. London: Verso.

Schmitt, C. 2005. Political Theology: Four Chapters on the Concept of Sovereignty. Chicago and London: The University of Chicago Press. 